\title{
Detoxification Enzyme Activity and Gene Expression in Diafenthiuron Resistant Whitefly, Bemisia tabaci
}

\author{
Bai-zhong Zhang ${ }^{1, \uparrow}$, Fan-chao Kong ${ }^{1, \dagger} \&$ Xin-nian Zeng ${ }^{1}$ \\ ${ }^{1}$ Key Lab of Pesticide and Chemical Biology, Ministry of Education, College of Natural Resources and \\ Environment, South China Agricultural University, Guangzhou, China \\ Correspondence: Xin-nian Zeng, Key Lab of Pesticide and Chemical Biology, Ministry of Education, College of \\ Natural Resources and Environment, South China Agricultural University, Guangzhou 510642, China. Tel: \\ 86-020-8528-4925. E-mail: zengxn@scau.edu.cn \\ ${ }^{\dagger}$ These authors contributed equally to this work.
}

Received: June 3, 2015 Accepted: July 15, 2015 Online Published: August 15, 2015

doi:10.5539/jas.v7n9p66 URL: http://dx.doi.org/10.5539/jas.v7n9p66

\begin{abstract}
B-biotype Bemisia tabaci has developed high levels of resistance to many insecticides. To investigate the risks and explore possible mechanisms of resistance to the diafenthiuron in B. tabaci, a 24.7-fold diafenthiuron resistant strain (TH-R) was established after selection for 20 generations compared with the susceptible strain (TH-S). Biochemical assays showed that the activity of cytochrome P450 towards $P$-NA was significantly higher (3.6-fold higher) in the TH-R strain than in the TH-S strain. Similarly, the carboxylesterase (COE) activity and Glutathione S-transferase (GST) activity were also significantly higher (2.55- and 1.65-fold higher, respectively) in the TH-R strain than in the TH-S strain. The expression of 5 of 7 P450 genes was significantly higher $(>2.3$-fold) in the TH-R strain than in the TH-S strain. The expression of COE1 was significantly higher $(>2.3$-fold) in the TH-R strain than in the TH-S strain. Cytochrome P450, COE and GST appear to be responsible for the resistance to diafenthiuron in $B$. tabaci. It is also valuable for usage of insecticides for resistance management and control of this species.
\end{abstract}

Keywords: Bemisia tabac, resistance, diafenthiuron, carboxylesterase (COE), glutathione S-transferase (GST), P450 (CYP6CM1)

\section{Introduction}

The cabbage whitefly, Bemisia tabaci (Hemiptera: Aleyrodidae), is an important pest that inflicts damage in temperate and tropical regions worldwide. It is a complex of biotypes that varies greatly involved in characteristics such as host range, fecundity, insecticide resistance ability to transmit plant viruses and induction of plant disorders (Dinsdale et al., 2010; De Barro et al., 2011), which has showed a strong ability to develop resistance to many insecticides including organophosphates, carbamates, pyrethroids, neonicotinoids and juvenile hormone mimics (Brown et al., 1995; Horowitz et al., 2004; Nauen \& Denholm, 2005). Furthermore, mechanisms of resistance to these insecticides were also widely studied (Nauen et al., 2002; Rauch \& Nauen, 2003; Karunker et al., 2008, 2009; Feng et al., 2009; Wang et al., 2010; Yang et al., 2013). However, the resistance to diafenthiuron and mechanisms for B. tabaci has not been reported.

Diafenthiuron is a thiourea derivative as a very useful entry in the available chemical insecticides against $B$. tabaci. It is also reported to be safe to parasitoids and predators (Ismail, 1997; Zuhua \& Shusheng, 1998) and can fit in integrated pest management (Delbeke et al., 1997; Sun \& Soo, 2000). So it is valuable to evaluate the risk of resistance development.

The most common reasons for insect resistance to most insecticides are enhanced metabolic detoxification and target-site insensitivity. It has been reported that the enhanced metabolism mediated by cytochrome P450 monooxygenase (P450) and glutathione S-transferase (GST) was reported to be involved in abamectin resistance (Wang \& Wu, 2007). The resistance to neonicotinoid and thiamethoxam is mediated in part by cytochrome $\mathrm{P} 450$ (Nauen et al., 2002; Rauch \& Nauen, 2003; Feng et al., 2009, 2010) In B. tabaci, a specific cytochrome P450, CYP6CM1 was involved in the resistance to imidacloprid and could metabolize this insecticide in vitro 
(Karunker et al., 2008, 2009). Another cytochrome P450 gene, CYP6CX1, was putatively involved in imidacloprid resistance in a field population of B. tabaci (Zhuang et al., 2011). Furthermore, increased cytochrome P450 indicated resistance to both imidacloprid and thiamethoxam (Bass et al., 2011). Alon et al. (2008) found that organophosphate resistance in B. tabaci is related to a point mutation in an ace1-type acetylcholinesterase and overexpression of COE1.

In our study, we reared the TH-R and TH-S strain on cabbage, and then studied the biochemical characteristics and gene expression profiles of their metabolic detoxification enzymes, including carboxylesterase (COE), GST and cytochrome P450. It appears that the increased enzyme activity and multiple up-regulated COE, GST and cytochrome P450 genes in the resistant strains that may be responsible for the development of resistance to insecticide. At the same time, it also provides the theoretical basis for a better understanding of the mechanism of resistance in B-biotype B. tabaci, and rational usage of insecticides for resistance management and control.

\section{Materials and Methods}

\subsection{Insect Materials}

Two B-type B. tabaci strains, the TH-R strain and the TH-R strain, were used in the experiments and reared as previous described (Feng et al., 2009; Xie et al., 2012). The TH-R strain exhibited over 24.7-fold resistance to diafenthiuron in comparison with the TH-S strain. Samples were collected from both strains at the following life stages: one-day-old unmated adults. Samples were frozen at $-80^{\circ} \mathrm{C}$ and stored for downstream RNA work.

\subsection{Bioassays}

A leaf-dip bioassay was used according to the methods of Feng et al. (2009) with slight modifications. The diafenthiuron was dissolved and diluted with distilled water. Leaf discs (22 $\mathrm{mm}$ in diameter) from cabbage plants (medium-sized leaves) were dipped in the insecticide solutions for $10 \mathrm{~s}$. After drying, the leaf discs were placed with their adaxial surface downwards onto a bed of agar $\left(2 \mathrm{~mL}\right.$ of $\left.15 \mathrm{~g} \mathrm{~L}^{-1}\right)$ in a flat-bottomed glass tube $(78 \mathrm{~mm}$ in length). Control groups were treated with distilled water applied to leaf discs in the same manner as the treatment groups. Each tube contained about 30 unsexed whitefly adults (within 5 days after eclosion) and was placed in an incubator at $25^{\circ} \mathrm{C}$ with a $14: 10 \mathrm{~h}$ light:dark photoperiod. Mortalities were recorded after $48 \mathrm{~h}$. Each treatment included four replicates, using 5-7 concentrations based on preliminary data.

\subsection{Insecticides and Chemicals}

Diafenthiuron (98.1\% technical crystal) was obtained from Foshan entry-exit inspection and quarantine. Fast Blue B and Coomassie Brilliant Blue (G-250) were purchased from Sigma Aldrich. Bovine serum albumin (BSA), glutathione reduced (GSH) (> 99.5\%) and NADPH (tetrasodium salt) $(>98 \%)$ were obtained from Roche Diagnostics (Indianapolis, IN), EDTA ( $>$ 99\%) was obtained from Amresco Inc., 1,4-dithioerythritol (DTT, > 99\%) was obtained from Merck Chemicals Ltd and phenylmethanesulfonyl fluoride (PMSF) was obtained from BBI (Blockbuster Inc.). 1-Naphthyl acetate ( $\alpha$-NA), 1-naphthol, 4-nitroanisole ( $p$-NA), p-nitrophenol ( $p$-nP), 1-chloro-2,4-dinitrobenzene (CDNB). TRIzol reagent was purchased from Invitrogen (USA). Taq DNA polymerase and DNA Marker DL 2000 were purchased from Sangon Company (Shanghai, China). Agarose, DNase I and SYBR Green I were purchased from TaKaRa (Dalian, China).

\subsection{Metabolic Enzyme Assays}

COE activity was determined using $\alpha$-naphthyl acetate as the substrate by measuring the $\mathrm{OD}_{600}$ according to the method of Van AsPeren et al. (1962) and Feng et al. (2009) with slight modification. 100 adults were homogenised in $0.2 \mathrm{M}$ phosphate buffer ( $\mathrm{pH} 6.0$ ). The homogenate was centrifuged at $4{ }^{\circ} \mathrm{C}$ and $10800 \times g$ for 15 $\mathrm{min}$, and then the supernatant was used as the enzyme source. A standard curve was prepared with 1-naphthol. The reaction mixture $(6 \mathrm{~mL})$ included: $\alpha$-NA $(0.3 \mathrm{mM})$, eserine $(0.1 \mathrm{mM})$, phosphate buffer $(0.04 \mathrm{M}, \mathrm{pH} 7.0)$ and enzyme solution $(0.1-0.5 \mathrm{~mL})$.

GST activity was determined using GSH and CDNB as substrates according to Wu and Miyata (2005) with slight modification. 150 adults were homogenised in $4 \mathrm{~mL}$ of $0.05 \mathrm{M}$ Tris- $\mathrm{HCl}$ buffer ( $\mathrm{pH}$ 7.5). The homogenate was centrifuged at $4{ }^{\circ} \mathrm{C}$ and $10800 \times \mathrm{g}$ for $15 \mathrm{~min}$, and then the supernatant was used as the enzyme source for the GST activity assay. The reaction mixture consisted of GSH $(50.0 \mathrm{mM})$, CDNB $(30.0 \mathrm{mM})$, and enzyme solution $(0.2 \mathrm{~mL})$. Changes in absorbance values were recorded at $340 \mathrm{~nm}$ for 5 min using a spectrophotometer (Unico, Shanghai, China).

Cytochrome P450 activity was assayed according to the method described by Yu and Nguyen (1992) and Feng et al. (2009) using $p$-nitroanisole as substrate with slight modification. 300 adults were homogenised in sodium phosphate buffer (0.1 M, pH 7.5, $1 \mathrm{mM}$ of EDTA, $0.1 \mathrm{mM}$ of DTT, $1 \mathrm{mM}$ of PTU and $1 \mathrm{mM}$ of PMSF). The 
homogenates were centrifuged at $10800 \times \mathrm{g}$ at $4{ }^{\circ} \mathrm{C}$ for $15 \mathrm{~min}$, and the supernatants were treated at $10800 \times \mathrm{g}$ at $4{ }^{\circ} \mathrm{C}$ for $20 \mathrm{~min}$ and used as the crude enzyme source. The reaction mixture consisted of $p$-nitroanisole $(2 \mu \mathrm{M})$, NADPH (9.6 mM) and enzyme sources. The mixture was incubated at $34{ }^{\circ} \mathrm{C}$ in an air atmosphere for 30 min. The $\mathrm{OD}_{405}$ value was recorded, and the quantity of the product was determined from a $p$-nitrophenol standard curve; the substrate $(0.02 \mathrm{mM})$ was dissolved in the same buffer used for the PNOD activity measurement. The reaction was started by adding NADPH $(10 \mathrm{mM} ; 10 \mu \mathrm{L})$, and the reaction was followed at $34{ }^{\circ} \mathrm{C}$ for 1 min with a spectrofluorometer. The wavelengths for excitation and emission were 380 and $460 \mathrm{~nm}$, and the slits were 5 and $10 \mathrm{~nm}$ respectively.

\subsection{Primer Design}

The primers for Quantitative Real-time PCR (qRT-PCR) were designed using primer3 input (http://primer3.ut.ee/). The primers were designed on the basis of sequences published in NCBI. The primers used were shown in Table 1.

Table 1. Sequences of primers used for the relative expression of the target genes from B. tabaci

\begin{tabular}{|c|c|c|c|}
\hline $\begin{array}{l}\text { Gene Name } \\
\text { (Accession. No) }\end{array}$ & $\begin{array}{l}\text { Primer sequences } \\
\text { (forward/reverse) }\end{array}$ & $\operatorname{Tm}\left({ }^{\circ} \mathrm{C}\right)$ & Product length $(\mathrm{bp})$ \\
\hline$E F 1 \alpha$ & F: TAGCCTTGTGCCAATTTCCG & 55.4 & 110 \\
\hline (EE600682) & R: CCTTCAGCATTACCGTCC & 56.0 & \\
\hline COE11 & F: CCATGCTGAGTTTCCAACCC & 57.5 & 86 \\
\hline (EF675184) & R: TGTGCATGTCAATAGCTGCC & 55.4 & \\
\hline$G S T$ & F: GTGGAGGAAAAACACCCTCA & 55.4 & 97 \\
\hline (EU723684) & R: AGTCGGTTTTTGGCCTCTTT & 53.4 & \\
\hline СУР6CM1 & F: CATCAAAGACCTCGTGAGCA & 55.4 & 128 \\
\hline (GQ214539) & R: TGCACAGCTTTCCTCATCTG & 55.4 & \\
\hline CYP6CX1 & F: CATCAAAGACCTCGTGAGCA & 55.4 & 114 \\
\hline (GQ330542) & R: TGCACAGCTTTCCTCATCTG & 55.4 & \\
\hline СРР $6 C X 4$ & F: TGTCTGCCATCACCACATTT & 51.3 & 113 \\
\hline (JN165265) & R: CTTAATTTCGCCGCATGATT & 55.4 & \\
\hline$C Y P 6 D W 3$ & F: ATCCACGACGCTTGCTACTT & 55.4 & 88 \\
\hline (JN165261) & R: CAAGACCCGTTCGATTTCAT & 55.35 & \\
\hline CYP6DZ6 & F: TGCGTTCATTTTCTTCATCG & 51.3 & 123 \\
\hline (JN165260) & R: TTCACGGATTCCACCTCTTC & 55.4 & \\
\hline CYР6A & F: TCGGAAACTACGCGGAAGTA & 55.4 & 101 \\
\hline (EU723677) & R: AGACCTAGAACGGGAATGCA & 55.4 & \\
\hline CYP9F & F: CTGTTCTGGGAAGACGTTGC & 57.5 & 114 \\
\hline (EU723679) & R: ATTGCGGGTCATGATGGAGA & 55.4 & \\
\hline
\end{tabular}

\subsection{Total RNA Isolation and Reverse Transcription}

Total RNAs were extracted from about 30 adults of $B$. tabaci using a Trizol reagent (Invitrogen, Carlsbad, USA) following the manufacturer's protocol. The resulting total RNA was resuspended in nuclease-free water and was quantified on a NanoDrop 2000 spectrophotometer (Thermo Scientific, Wilmington, DE). First-strand cDNAs

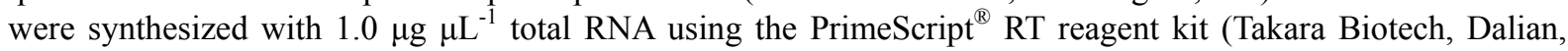
China) according to the manufacturer's protocol.

\subsection{Quantitative Real-Time PCR (qRT-PCR)}

The relative expression levels of CYP6CM1, CYP6CX1,CYP6CX4, CYP6DW3, CYP6DZ6, CYP6A, CYP9F, $C O E 1$, and $G S T$ from the adults of $B$. tabaci were examined using qRT-PCR. Each reaction was performed in a 
$20 \mu \mathrm{L}$ mixture containing $1 \mu \mathrm{L}$ of cDNA, $10 \mu \mathrm{L}$ of SYBR Green qRT-PCR SuperMix-UDG, $0.15 \mu \mathrm{L}$ of each primer, and $8.7 \mu \mathrm{L}$ of $\mathrm{H}_{2} \mathrm{O}$. All samples, including a 'no-template' negative control, were performed in a $20 \mu \mathrm{L}$ mixture containing $1 \mu \mathrm{L}$ of cDNA, $10 \mu \mathrm{L}$ of SYBR Green qRT-PCR SuperMix-UDG, $0.15 \mu \mathrm{L}$ of each primer, and $8.7 \mu \mathrm{L}$ of $\mathrm{H}_{2} \mathrm{O}$. The amplification efficiency of the target genes and housekeeping gene $(E F-1 \alpha)$ were estimated using $E=10^{-1} /$ slope -1 , where the slope was derived from the plot of the cycle threshold $\left(\mathrm{C}_{t}\right)$ value versus the log of the serially diluted template concentration. The optimised qRT-PCR program consisted of an initial step at $50{ }^{\circ} \mathrm{C}$ for $2 \mathrm{~min}, 94{ }^{\circ} \mathrm{C}$ or $2 \mathrm{~min}$, followed by 50 cycles of $94{ }^{\circ} \mathrm{C}$ for $15 \mathrm{~s}$ and $60{ }^{\circ} \mathrm{C}$ for $30 \mathrm{~s}$. After the cycling protocol, melting curves were obtained by increasing the temperature from 60 to $95{ }^{\circ} \mathrm{C}\left(0.2^{\circ} \mathrm{C} \cdot \mathrm{s}^{-1}\right)$ to denature the double-stranded DNA. The qRT-PCR amplifications were carried out in 96-well plates. The assays were run in an ABI 7500 system using the SDS v.1.4 application software (Applied Biosystems). Quantification of the transcript level of 9 detoxification genes mRNA was performed using the comparative $2^{-\Delta \Delta C T}$ method (Pfaffl, 2001).

\subsection{Statistical Analysis}

Data statistics and bioassay analysis were performed on Excel (2010) and PoloPlus. Statistical analysis was performed by one-way ANOVA and Tukey's test $(\mathrm{P}<0.05)$ to compare the expression levels of COE1, GST and cytochrome P450 genes by using the software InStat v.3.0 (GraphPad Software, San Diego, CA).

\section{Results}

\subsection{Determination of Resistance Levels to Insecticides in B. tabaci}

To investigate the risks and to determine possible mechanisms of resistance to diafenthiuron in $B$. tabaci, The TH-R strain was selected in the laboratory. A 24.7-fold TH-R strain was established after selection for 20 generations compared with the TH-S strain (Table 2).

\subsection{COE Activity, GST Activity and Cytochrome P450 Activity in the TH-R and TH-S Strain}

CarE activity was 2.55-fold higher for the TH-R strain than for the TH-S strain (Figure 1A). GST activity was 1.65-fold higher for the TH-R strain than for the TH-S strain (Figure 1B). Cytochrome P450 activity towards PNA was 3.56-fold higher for the TH-R strain than for the TH-S strain (Figure 1C). Cytochrome P450 activity towards $P$-NA was highest for the TH-R strain than for the TH-S strain in the three of them.

\subsection{Gene Expression Profiles for COE, GST and Cytochrome P450 Genes in the TH-R and TH-S Strain}

To investigate the expression profiles of putative detoxification genes (one GST, one COE1 and 7 cytochrome P450 genes) in the TH-R and TH-S strain, qRT-PCR analyses were used. The relative expression of all P450 genes in the TH-R strain relative to the TH-S strain is shown in Figure 4. Of the7 P450 genes, 2 (CYP6CMI and CYP6A) had $>1$-fold higher expression in the TH-R strain than in the TH-S strain, five (CYP6CX1, CYP6CX4, CYP6DW3, CYP6DZ6, and CYP9F) had > 2.3-fold higher expression in the TH-R strain than in the TH-S strain. In addition, the expression level of GST was 2.1-fold higher in the TH-R strain than in the TH-S strain (Figure 2), while the expression of COE1 did not significantly differ between the TH-R strain and the TH-S strain (Figure $3)$.

Table 2. Toxicity of detoxification to $B$. tabaci strains

\begin{tabular}{llllc}
\hline Strains & Slope \pm S.E & $\mathrm{LC}_{50}\left(\mu \mathrm{g} \cdot \mathrm{mL}^{-1}\right)(95 \% \mathrm{FL})$ & $\chi^{2}(\mathrm{df})$ & $\mathrm{RF}$ \\
\hline TH-S & $2.71 \pm 0.27$ & $12.43(10.15-15.30)$ & $23.43(17)$ & 1 \\
TH-R & $3.12 \pm 0.30$ & $307.47(249.81-378.91)$ & $28.87(17)$ & 24.73 \\
\hline
\end{tabular}

Note. Resistance Factor $(\mathrm{RF})=\mathrm{LC}_{50}$ of the TH-R strain / $\mathrm{LC}_{50}$ of the TH-S strain. 

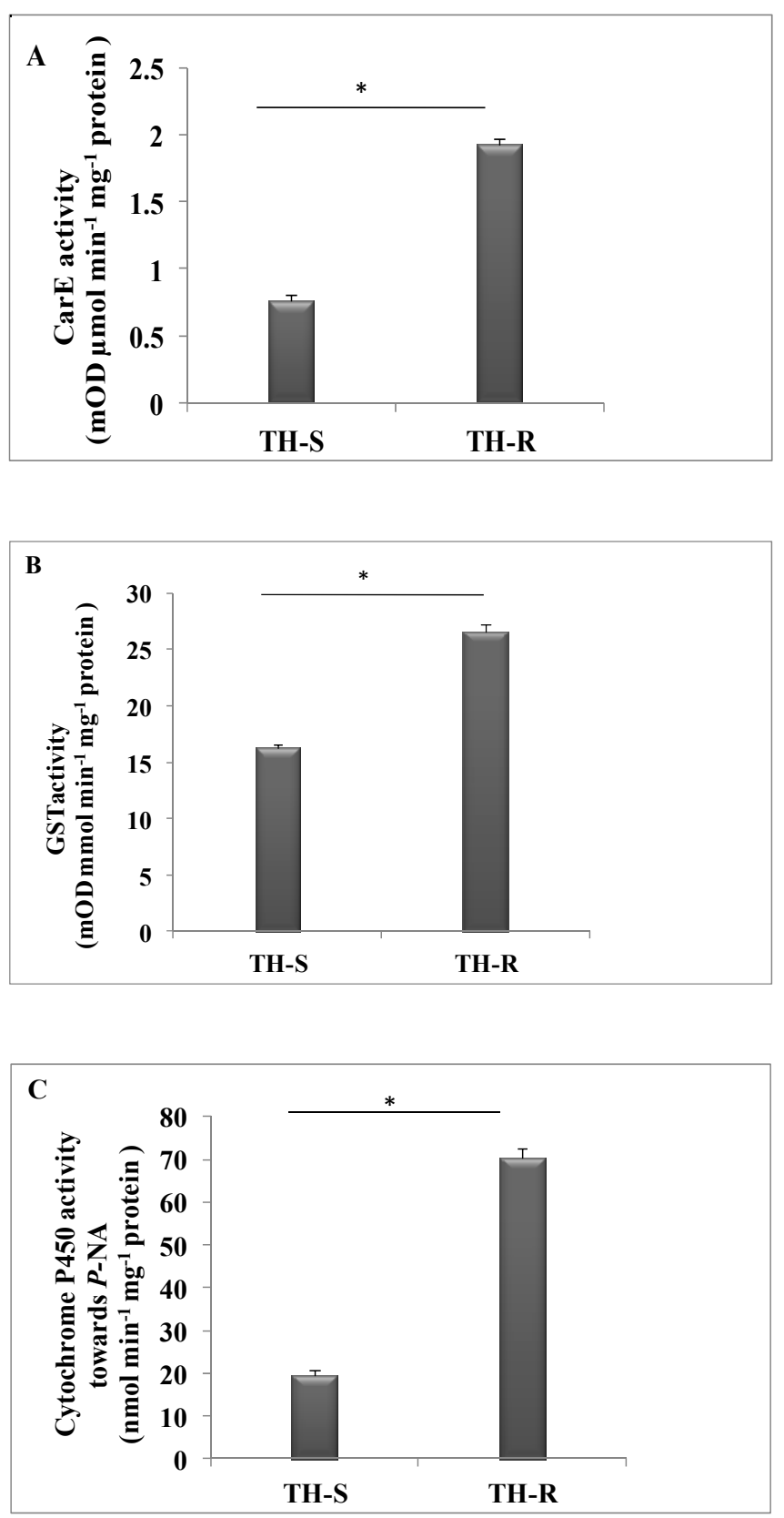

Figure 1. Activities of detoxification enzymes of the TH-R strain and the TH-S strain. (A) COE; (B) GST; (C) cytochrome P450 towards $P$-NA. Significant differences are indicated by an asterisk (one-way ANOVA, $P<0$. 05; LSD test) 


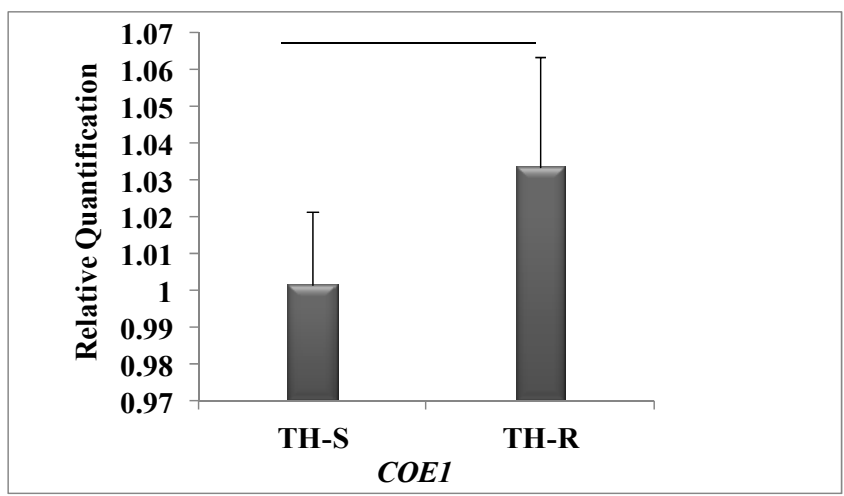

Figure 2. Expression profiles of COE1 in the TH-R strain relative to the TH-S strain. Significant differences are indicated by an asterisk (one-way ANOVA, $P<0.05$; LSD test)

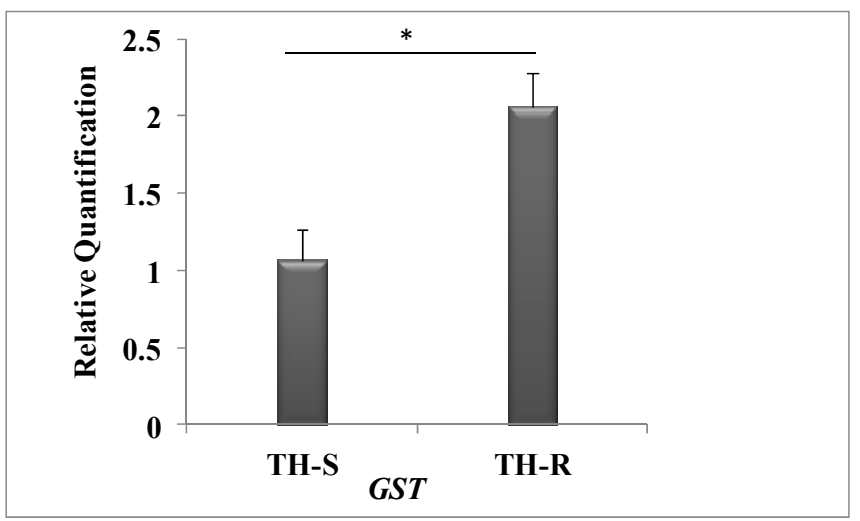

Figure 3. Expression profiles of GST in the TH-R strain relative to the TH-S strain. Significant differences are indicated by an asterisk (one-way ANOVA, $P<0.05$; LSD test)

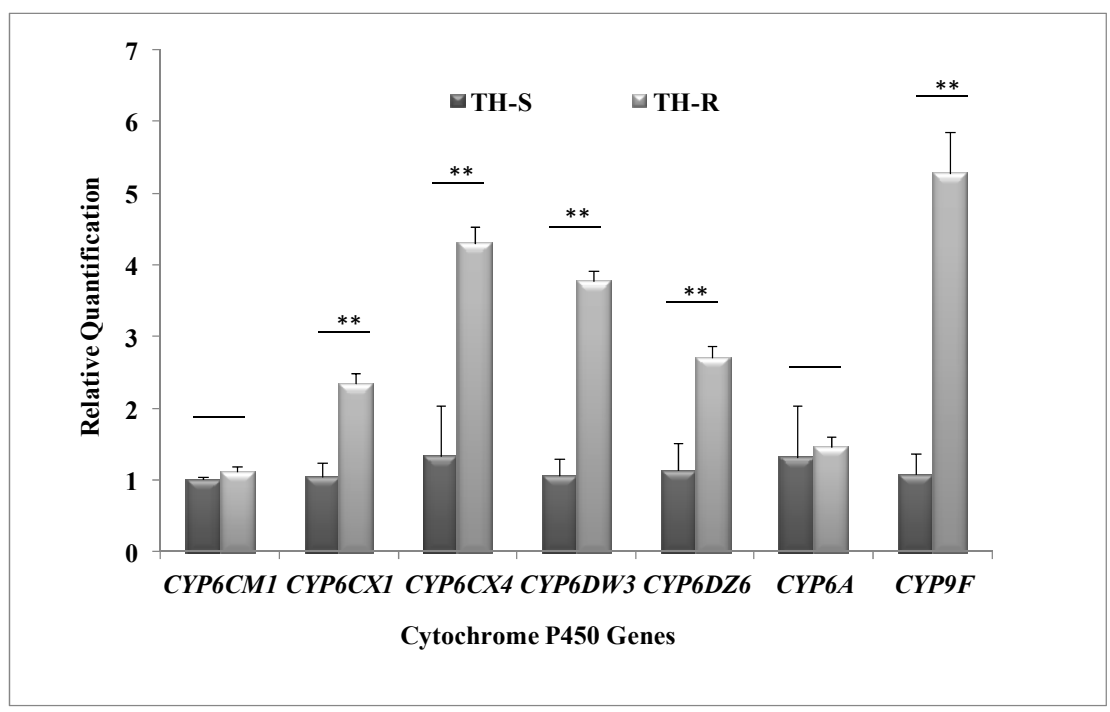

Figure 4. Expression profiles of P450 genes in the TH-R strain relative to the TH-S strain. Significant differences are indicated by an asterisk in the same gene (one-way ANOVA, $P<0.05$; LSD test)

\section{Discussion}

B. tabaci has developed high resistance to some commonly used insecticides (Kady \& Devine, 2003; Roditakis 
et al., 2005; Ahmad, 2007). Typically, enhanced metabolic detoxification among insects may contribute to insecticide resistance (Low et al., 2007), the metabolic detoxification system in insects consists of three major groups of enzymes. The phase I detoxification enzymes, acting on a broad range of substrates directly to reduce their toxicity, are represented by cytochrome P450. The phase II enzymes, including GST, UDP-glucuronosyltransferases (UGTs), and COE, facilitate the excretion of hydrophobic toxic compounds by improving their hydrophilicity. Many studied indicated that increased levels of detoxification gene expression are known to result in increased levels of detoxification enzymes and detoxification enzymes activities that are responsible for insecticide resistance (Liu \& Scott, 1998; Liu et al., 2011; Schule, 2011; Gong et al., 2013; Zhang et al., 2015).

The biochemical characteristics and gene expression profiles of detoxification enzymes in the TH-R and TH-S strain were compared in the present study, respectively, as enhanced metabolic detoxification often contributes to insecticide resistance among insects ( $\mathrm{Li}$ et al., 2007). The activity of cytochrome P450 towards $P$-NA was significantly greater in the TH-R strain than in the TH-S strain in our study. This is somewhat consistent with that the major mechanism in all samples investigated so far has appeared to be enhanced detoxification by cytochrome P450 (Rauch \& Nauen, 2003). Furthermore, the cytochrome P450 system has been previously reported to be involved in the resistance to many insecticides in many insects, including abamectin resistance in Leptinotarsa decemlineata (Argentine et al., 1992), Tetranychus urticae (Stumpf \& Nauen, 2002) and B. tabaci (Wang \& Wu, 2007), permethrin resistance in Culex quinquefasciatus (Liu et al., 2011; Gong et al., 2013), and imidacloprid resistance in Nilaparvata lugens (Bass et al., 2011). In particular, the resistance of B. tabaci to imidacloprid was strongly related to enhanced detoxification by cytochrome P450 (Nauen et al., 2002; Feng et al., 2010), and cytochrome P450 activity was significantly greater in the resistant strains than in the corresponding susceptible strains (Rauch \& Nauen, 2003). These are consistent with our results that cytochrome P450 may be the major mechanism in all detoxification enzymes investigated in B. tabaci.

In addition to comparing enzyme activities in the TH-R strain and the TH-S strain, the expression profiles of 7 cytochrome P450 genes were also compared. Expression levels for CYP6CX1, CYP6CX4, CYP6DW3, CYP6DZ6, and $C Y P 9 F$ were significantly higher in the TH-R strain than in the TH-S strain. In addition, though the other two cytochrome P450 genes (CYP6CM1 and CYP6A) were not overexpressed in the TH-R strain, they could be significantly induced in the TH-R strain or the TH-S strain, respectively (data not shown). In previous studies, Rauch and Nauen (2003) and Cahill et al. (1996) reported that enhanced metabolic detoxification resulting from increased expression of cytochrome P450 is a major factor resulting in pest tolerance to neonicotinoid insecticides. Cytochrome P450s metabolize endogenous compounds, and the CYP6 family has been implicated in insecticide resistance more than any other cytochrome P450 families (Pavek \& Dvorak, 2008; Scott, 2008; Puinean et al., 2011). For example, CYP6CM1 and CYP9F have also been reported that linked with imidacloprid resistance in whitefly (Karunker et al., 2008; Qiu et al., 2009), CYP6CX1 exhibited significantly higher mRNA in imidacloprid and thiamethoxam resistance in whitefly (Zhuang et al., 2011; Yang et al., 2013). These findings are somewhat consistent with that CYP6CM1, CYP6CX1, and CYP9F may be not only involved in imidacloprid and thiamethoxam resistance, but also involved in diafenthiuron resistance in whitefly. In the present study, expression levels of CYP6DW3, CYP6DZ7, and CYP6CX5 were significantly greater in B. tabaci Q than in B, suggesting that the enzymes encoded by these genes may contribute to the different sensitivities to insecticides (Guo et al., 2014). In our study, the overexpression of CYP6DW3, CYP6DZ6, and CYP6CX4 in the TH-R strain was also observed, suggesting that multiple cytochrome P450s were involved in insecticide resistance. At the same time, the target-site modifications and enhanced detoxification for imidacloprid resistance have been identified. Studies have indicated that a target-site mutation, Y151S, within the nAChR N1 $\alpha 1$ and N1 $\alpha 3$ subunits, which was involved in imidacloprid resistance in the laboratory-selected brown planthopper (Liu et al., 2005).

In addition to cytochrome P450, GST and COE could also be involved in the detoxification of allelochemicals (Karunker et al., 2008). Enhanced expression of GST has been shown to be a mechanism of resistance to DDT and organophosphates, and has also been implicated in resistance to pyrethroids in some insects (Huang et al., 1998; Ranson et al., 2001; Vontas et al., 2001). GST activity and single GST expression were significantly higher in the TH-R strain than in the TH-S strain in the present study. The involvement of this GST in the resistance of the TH-R strain to diafenthiuron clearly warrants further investigation, including functional validation of the ability of this enzyme to metabolize diafenthiuron and/or its primary metabolites.

Organophosphate resistance in the B-biotype of $B$. tabaci is associated with a point mutation in an ace1-type acetylcholinesterase and overexpression of COEs (Alon et al., 2008). COE1 displayed a higher level of expression in thiamethoxam resistance in B-biotype B. tabaci by Yang et al. (2014). COE activity was 
significantly higher in the TH-R strain than in the TH-S strain in our present study. Although COE1 was not difference between the TH-R strain and the TH-S strain, significant induction by diafenthiuron was observed. Further evidence was showed that the activities of COE of the resistant strain increased significantly (Rauch \& Nauen, 2003). Alon et al. (2008) also showed that COE1 and another COE displayed a higher level of expression, whereas, only a two-fold increase in expression of COE2 in the resistant strain compared to the susceptible strain. This was consistent with some of our results and those of previous studies. These findings strongly suggest that $\mathrm{COE}$ and cytochrome $\mathrm{P} 450$ were responsible for diafenthiuron resistance.

\section{Conclusions}

We have shown that selection of the TH-R strain with diafenthiuron over many generations has induced significant changes in activities and gene expression of detoxification enzymes, indicating that enhanced detoxification by cytochrome P450, COE and Glutathione GST are mainly responsible for this resistance. The target insensitivity or inheritance patterns of diafenthiuron resistance in $B$. tabaci will also require additional research in order to confirm the resistance mechanism and to establish more efficient management strategies for this pest.

\section{Acknowledgements}

This work was funded by Special Fund for Agro-scientific Research in the Public Interest (201303019-01).

\section{References}

Ahmad, M. (2007). Potentiation/antagonism of pyrethroids with organophosphate insecticides in Bemisia tabaci (Homoptera: Aleyrodidae). Journal of Economic Entomology, 100, 886-893. http://dx.doi.org/10.1093/jee/100.3.886

Alon, M., Alon, F., Nauen, R., \& Morin, S. (2008). Organophosphates' resistance in the B-biotype of Bemisia tabaci (Hemiptera: Aleyrodidae) is associated with a point mutation in an ace1-type acetylcholinesterase and overexpression of carboxylesterase. Insect Biochemistry and Molecular Biology, 38, 940-949. http://dx.doi.org/10.1016/j.ibmb.2008.07.007

Argentine, J. A., Clark, J. M., \& Lin, H. (1992). Genetics and biochemical mechanisms of abamectin resistance in two isogenic strains of Colorado potato beetle. Pesticide Biochemistry and Physiology, 44, 191-207. http://dx.doi.org/10.1016/0048-3575(92)90090-M

Bass, C., Carvalho, R. A., Oliphant, L., Puinean, A. M., Field, L. M., Nauen, R., ... Gorman, K. (2011). Overexpression of a cytochrome P450 monooxygenase, CYP6ER1, is associated with resistance to imidacloprid in the brown planthopper, Nilaparvata lugens. Insect Molecular Biology, 20, 763-773. http://dx.doi.org/10.1111/j.1365-2583.2011.01105.x

Bass, C., Puinean, A. M., Andrews, M., Cutler, P., Daniels, M., Elias, J., ... Slater, R. (2011). Mutation of a nicotinic acetylcholine receptor beta subunit is associated with resistance to neonicotinoid insecticides in the aphid Myzus persicae. BMC Neuroscience, 12, 51. http://dx.doi.org/10.1186/1471-2202-12-51

Brown, J. K., Frohlich, D. R., \& Rosell, R. C. (1995). The sweetpotato or silverleaf B. tabaci: Biotypes of Bemisia tabaci or a species complex? Annual Review of Entomology, 40, 511-534. http://dx.doi.org/10.1146/annurev.en.40.010195.002455

Cahill, M., Gorman, K., Day, S., Denholm, I., Elbert, A., \& Nauen, R. (1996). Baseline determination and detection of resistance to imidacloprid in Bemisia tabaci (Homoptera: Aleyrodidae). Bulletin of Entomological Research, 86, 343-349. http://dx.doi.org/10.1017/S000748530003491X

De Barro, P. J., Liu, S. S., Boykin, L. M., \& Dinsdale, A. B. (2011). Bemisia tabaci: a statement of species status. Annual Review of Entomology, 56, 1-19. http://dx.doi.org/10.1146/annurev-ento-112408-085504

Delbeke, F., Vercruysse, P., Tirry, L., Clercq, P., \& Degheele, D. (1997). Toxicity of diflubenzuron, pyriproxyfen, imidacloprid and diafenthiuron to the predatory bug Orius laevigatus (Het.: Anthocoridae). Entomophaga, 42, 349-358. http://dx.doi.org/10.1007/BF02769828

Dinsdale, A., Cook, L., Riginos, C., Buckley, Y. M., \& De Barro, P. (2010). Refined global analysis of Bemisia tabaci (Hemiptera: Sternorrhyncha: Aleyrodoidea: Aleyrodidae) mitochondrial cytochrome oxidase 1 to identify species level genetic boundaries. Annals of the Entomological Society of America, 103, 196-208. http://dx.doi.org/10.1603/AN09061

Feng, Q., Davey, K. G., Pang, A. S. D., Ladd, T. R., Retnakaran, A., Tomkins, B. L., ... Palli, S. R. (2001). Developmental expression and stress induction of glutathione S-transferase in the spruce budworm, 
Choristoneura fumiferana. Journal of Insect Physiology, 47, 1-10. http://dx.doi.org/10.1016/S0022-1910(00)00093-7

Feng, Y., Wu, Q., Wang, S., Chang, X., Xie, W., Xu, B., \& Zhang, Y. (2010). Cross-resistance study and biochemical mechanisms of thiamethoxam resistance in B-biotype Bemisia tabaci (Hemiptera: Aleyrodidae). Pest Management Science, 66, 313-318. http://dx.doi.org/10.1002/ps.1877

Feng, Y., Wu, Q., Wang, S., Chang, X., Xie, W., Xu, B., \& Zhang, Y. (2010). Cross-resistance study and biochemical mechanisms of thiamethoxam resistance in B-biotype Bemisia tabaci (Hemiptera: Aleyrodidae). Pest Management Science, 66, 313-318. http://dx.doi.org/10.1002/ps.1877

Gong, Y., Li, T., Zhang, L., Gao, X., \& Liu, N. (2013). Permethrin Induction of Multiple Cytochrome P450 Genes in Insecticide Resistant Mosquitoes, Culex quinquefasciatus. International Journal of Biological Sciences, 9, 863-871. http://dx.doi.org/10.7150/ijbs.6744

Guo, L., Xie, W., Wang, S., Wu, Q., Li, R., Yang, N., ... Zhang, Y. (2014). Detoxification enzymes of Bemisia tabaci B and Q: biochemical characteristics and gene expression profiles. Pest Management Science, 70, 1588-1594. http://dx.doi.org/10.1002/ps.3751

Horowitz, A. R., Kontsedalov, S., \& Ishaaya, I. (2004). Dynamics of resistance to the neonicotinoids acetamiprid and thiamethoxam in Bemisia tabaci (Homoptera: Aleyrodidae). Journal of Economic Entomology, 97, 2051-2056. http://dx.doi.org/10.1093/jee/97.6.2051

Huang, H. S., Hu, N., Yao, Y., Wu, C., Chiang, S., \& Sun, C. (1998). Molecular cloning and heterologous expression of a glutathione S-transferase involved in insecticide resistance from the diamondback moth, Plutella xylostella. Insect Biochemistry and Molecular Biology, 28, 651-658. http://dx.doi.org/10.1016/S0965-1748(98)00049-6

Ismail, S. M. M. (1997). Selectivity and joint action of Melia azedarach L. fruit extracts with Certain acaricides to Tetranychus urticae Kock and Stethorus gilvifrons Mulsant. Annals of Agricultural Science, 35, 605-618.

Jones, C. M., Daniels, M., Andrews, M., Slater, R., Lind, R. J., Gorman, K., ... Denholm, I. (2011). Age-specific expression of a $\mathrm{P} 450$ monooxygenase (CYP6CM1) correlates with neonicotinoid resistance in Bemisia tabaci. Pesticide Biochemistry and Physiology, 101, 53-58. http://dx.doi.org/10.1016/j.pestbp.2011.07.004

Kady, H. E., \& Devine, G. J. (2003). Insecticide resistance in Egyptian populations of the cotton whitefly, Bemisia tabaci (Hemiptera: Aleyrodidae). Pest Management Science, 59, 865-871. http://dx.doi.org/10.1002/ps.687

Karunker, I., Benting, J., Lueke, B., Ponge, T., Nauen, R., Roditakis, E., ... Morin, S. (2008). Over-expression of cytochrome P450 CYP6CM1 is associated with high resistance to imidacloprid in the B and Q biotypes of Bemisia tabaci (Hemiptera: Aleyrodidae). Insect Biochemistry and Molecular Biology, 38, 634-644. http://dx.doi.org/10.1016/j.ibmb.2008.03.008

Karunker, I., Morou, E., Nikou, D., Nauen, R., Sertchook, R., Stevenson, B. J., ... Vontas, J. (2009). Structural model and functional characterization of the Bemisia tabaci CYP6CM1vQ, a cytochrome P450 associated with high levels of imidacloprid resistance. Insect Biochemistry and Molecular Biology, 39, 697-706. http://dx.doi.org/10.1016/j.ibmb.2009.08.006

Li, X., Schuler, M. A., \& Berenbaum, M. R. (2007). Molecular mechanisms of metabolic resistance to synthetic and natural xenobiotics. Annual Review of Entomology, 52, 231-253. http://dx.doi.org/10.1146/annurev.ento.51.110104.151104

Lindroth, R. L., \& Weisbrod, A. V. (1991). Genetic variation in response of the gypsy moth to aspen phenolic glycosides. Biochemical Systematics and Ecology, 19, 97-103. http://dx.doi.org/10.1016/0305-1978(91)90031-T

Liu, N., \& Scott, J. G. (1998). Increased transcription of CYP6D1 causes cytochrome P450-mediated insecticide resistance in house fly. Insect Biochemistry and Molecular Biology, 28, 531-535. http://dx.doi.org/10.1016/S0965-1748(98)00039-3

Liu, N., Li, T., Reid, W. R., Yang, T., \& Zhang, L. (2011). Multiple Cytochrome P450 Genes: Their Constitutive Overexpression and Permethrin Induction in Insecticide Resistant Mosquitoes, Culex quinquefasciatus. Plos One, 6, e23403. http://dx.doi.org/10.1371/journal.pone.0023403

Liu, Z. W., Williamson, M. S., Lansdell, S. J., Denholm, I., Han, Z. J., \& Millar, N. S. (2005). A nicotinic acetylcholine receptor mutation conferring target-site resistance to imidacloprid in Nilaparvata lugens 
(brown planthopper). Proceedings of the National Academy of Sciences of the United States of America, 102, 8420-8425. http://dx.doi.org/10.1073/pnas.0502901102

Low, W. Y., Ng, H. L., Morton, C. J., Parker, M. W., Batterham, P., \& Robin, C. (2007). Molecular evolution of glutathione S-transferases in the genus drosophila. Genetics, 177, 1363-1375. http://dx.doi.org/10.1534/genetics.107.075838

Nauen, R., \& Denholm, I. (2005). Resistance of insect pests to neonicotinoid insecticides: Current status and future prospects. Archives of Insect Biochemistry and Physiology, 58, 200-215. http://dx.doi.org/10.1002/arch.20043

Nauen, R., Stumpf, N., \& Elbert, A. (2002). Toxicological and mechanistic studies on neonicotinoid cross resistance in Q-type Bemisia tabaci (Hemiptera: Aleyrodidae). Pest Management Science, 58, 868-875. http://dx.doi.org/10.1002/ps.557

Pfaffl, M. W. (2001) A new mathematical model for relative quantification in real-time RT-PCR. Nucleic Acids Research, 29, e45-e45. http://dx.doi.org/10.1093/nar/29.9.e45

Puinean, A. M., Foster, S. P., Oliphant, L., Denholm, I., Field, L. M., Millar, N. S., ... Bass, C. (2010). Amplification of a cytochrome P450 gene is associated with resistance to neonicotinoid insecticides in the aphid Myzus persicae. Plos Genetics, 6, e1000999. http://dx.doi.org/10.1371/journal.pgen.1000999

Qiu, B., Liu, L., Li, X., Mathur, V., Qin, Z., \& Ren, S. (2009). Genetic mutations associated with chemical resistance in the cytochrome P450 genes of invasive and native Bemisia tabaci (Hemiptera: Aleyrodidae) populations in China. Insect Science, 16, 237-245. http://dx.doi.org/10.1111/j.1744-7917.2009.01253.x

Ranson, H., Rossiter, L., Ortelli, F., Jensen, B., Wang, X., Roth, C. W., ... Hemingway, J. (2001). Identification of a novel class of insect glutathione S-transferases involved in resistance to DDT in the malaria vector Anopheles gambiae. Biochemical Journal, 359, 295-304. http://dx.doi.org/10.1042/0264-6021:3590295

Rauch, N., \& Nauen, R. (2003). Identification of biochemical markers linked to neonicotinoid cross resistance in Bemisia tabaci (Hemiptera: Aleyrodidae). Archives of Insect Biochemistry and Physiology, 54, 165-176. http://dx.doi.org/10.1002/arch.10114

Roditakis, E., Roditakis, N. E., \& Tsagkarakou, A. (2005). Insecticide resistance in Bemisia tabaci (Homoptera : Aleyrodidae) populations from Crete. Pest Management Science, 61, 577-582. http://dx.doi.org/10.1002/ps.1029

Schuler, M. A. (2011). Review P450s in plant-insect interactions. Biochimica et Biophysica Acta (BBA)-Proteins and Proteomics, 1814, 36-45. http://dx.doi.org/10.1016/j.bbapap.2010.09.012

Scott, J. G. (2008). Insect cytochrome P450s: thinking beyond detoxification. Recent Advances in Insect Physiology, Toxicology and Molecular Biology, 1, 17-124.

Shi, Z., \& Liu, S. (1998). Toxicity of insecticides commonly used in vegetable fields to the diamond back moth, Plutella xylostella and its parasite, Cotesia plutellae. Chinese Journal of Biological Control, 141, 53-57.

Stumpf, N., \& Nauen, R. (2002). Biochemical markers linked to abamectin resistance in Tetranychus urticae (Acari: Tetranychidae). Pesticide Biochemistry and Physiology, 72, 111-121. http://dx.doi.org/10.1006/pest.2001.2583

Van Asperen, K. A. (1962). Study of housefly esterases by means of a sensitive colorimetric method. Journal of Insect Physiology, 8, 401-416. http://dx.doi.org/10.1016/0022-1910(62)90074-4

Vontas, J. G., Small, G. J., \& Hemingway, J. (2001). Glutathione S-transferases as antioxidant defence agents confer pyrethroid resistance in Nilaparvata lugens. Biochemical Journal, 357, 65-72. http://dx.doi.org/10.1042/0264-6021:3570065

Wang, L., \& Wu, Y. (2007). Cross-resistance and biochemical mechanisms of abamectin resistance in the B-type Bemisia tabaci. Journal of Applied Entomology, $131, \quad$ 98-103. http://dx.doi.org/10.1111/j.1439-0418.2006.01140.x

Wang, Z., Yan, H., Yang, Y., \& Wu, Y. (2010). Biotype and insecticide resistance status of the whitefly Bemisia tabaci from China. Pest Management Science, 66, 1360-1366. http://dx.doi.org/10.1002/ps.2023

Wu, G., \& Miyata, T. (2005). Susceptibilities to methamidophos and enzymatic characteristics in 18 species of pest insects and their natural enemies in crucifer vegetable crops. Pesticide Biochemistry and Physiology, 82, 79-93. http://dx.doi.org/10.1016/j.pestbp.2005.01.001 
Xie, W., Meng, Q., Wu, Q., Wang, S., Yang, X., Yang, N., ... Zhang, Y. (2012). Pyrosequencing the Bemisia tabaci Transcriptome Reveals a Highly Diverse Bacterial Community and a Robust System for Insecticide Resistance. Plos One, 7, e35181. http://dx.doi.org/10.1371/journal.pone.0035181

Yang, N., Xie, W., Jones, C. M., Bass, C., Jiao, X., Yang, X., ... Zhang, Y. (2013). Transcriptome profiling of the whitefly Bemisia tabaci reveals stage-specific gene expression signatures for thiamethoxam resistance. Insect Molecular Biology, 22, 485-496. http://dx.doi.org/10.1111/imb.12038

Yoo, S. S., \& Kim, S. S. (2000). Comparative toxicity of some pesticides to the predatory mite, Phytoseiulus persimilis (Acarina: Phytoseiidae) and the twospotted spider mite, Tetranychus urticae (Acarina: Tetranychidae). Korean Journal of Entomology, 30, 235-241. http://dx.doi.org/10.1023/A:1016585607728

Yoshiyama, M., \& Shukle, R. H. (2004). Molecular cloning and characterization of a glutathione S-transferase gene from Hessian fly (Diptera: Cecidomviidae). Annals of the Entomological Society of America, 97, 1285-1293. http://dx.doi.org/10.1603/0013-8746(2004)097[1285:MCACOA]2.0.CO;2

Yu, S. J., \& Nguyen, S. N. (1992). Detection and biochemical characterization of insecticide resistance in the diamondback moth. Pesticide Biochemistry and Physiology, 44, 74-81. http://dx.doi.org/10.1016/0048-3575(92)90011-N

Zhang, B., Kong, F., Wang, H., Gao, X., Zeng, X., \& Shi, X. (2015). Insecticide induction of o-demethylase activity and expression of cytochrome p450 genes in the red imported fire ant (Solenopsis invicta Buren). $J$. Integr. Agr., 15, in press. http://dx.doi.org/10.1016/S2095-3119(15)61072-3

Zhuang, H., Wang, K., Zheng, L., Wu, Z., Miyata, T., \& Wu, G. (2011). Identification and characterization of a cytochrome P450 CYP6CX1 putatively associated with insecticide resistance in Bemisia tabaci. Insect Science, 18, 484-494. http://dx.doi.org/10.1111/j.1744-7917.2010.01380.x

\section{Copyrights}

Copyright for this article is retained by the author(s), with first publication rights granted to the journal.

This is an open-access article distributed under the terms and conditions of the Creative Commons Attribution license (http://creativecommons.org/licenses/by/3.0/). 